UDC $141.7: 130.2$

DOI: $10.21847 / 1728-9343.2019 .1(159) .158006$

HURZHY KSENIIA,

Vasyl' Stus Donetsk National University (Vinnytsia, Ukraine)

e-mail: kseniia_gurzhi@ukr.net, ORCID 0000-0003-3663-6505

\title{
CITY AND ITS RESEARCHERS: SOCIAL-PHILOSOPHICAL FOCUS ON THE CONCEPTS AND EXPLANATIONS OF THE CITY PHENOMENON
}

\begin{abstract}
The article deals with the main theoretical and methodological approaches to the analysis and definition of the city. It is highlighted that modern authors again and again draw attention to the need for a holistic approach to the phenomenon of the city and tend to multidisciplinary urban studies. In the Ukrainian philosophical thought, the beginning of this work is laid in the philosophy of the city by L. Radionova, who proposes "to build a city in the cultural space as a kind of ontological idea", in viewing the city as the world of human existence by M. Karpovets or presenting the idea of the city as its myth. At the present stage under the conditions of civilizational crises and collision of various cultural orientations unfolding in urban spaces, it becomes clear that the city is not only an arena for these processes, but sometimes also their condition, an active participant and, in the end, their consequence. There is a necessity to develop a theory of the city that could simultaneously comprehend the city as a dynamic cultural form in general and as specific processes that take place in urban environments. The article deals with the main theoretical and methodological approaches in urban studies. The focus is on new multidisciplinary approaches to the phenomenon of city. Such us the theory of the own logic of the cities according to the research team of Darmstadt University; and the SPACE (D) system that focuses on the city from the standpoint of sociology, politics, architecture, city culture, urban economics and city data.
\end{abstract}

Key words: myth of the city; philosophy of the city; own logic of cities; urbanistic discourse.

Introduction. The city, probably, is listed as research object, to study which using methods from one area of science, is not enough. Currently equal urbanist discourse has a long history of formation, the most intense period of which dates from the beginning of the $X X$ century, when "urban topics" were allocated to a separate branch in social studies. This was preceded by works of E. Durkheim, G. Simmel, M. Weber, E. Cassirer, and Benjamin, who substantiated the possibilities of systematic, symbolic, anthropological, cultural, sociological, and other urban and urban resident's studies. In particular, the Ukrainian urbanist M. Prepotenskaya calls Max Weber a pioneer, who laid the foundations for understanding the city as a social space, and a citizen as a socially active person (Prepotenskaya, 2014). Weber himself defines the city as a union of citizens with common responsibilities but equal before the Christian ritual (Weber, 2001: 368).

Analysis of studies and publications. XX century opens for the city researchers with a new epistemological methodology. On the one hand, this happened thanks to the Annales school (Lucien Febvre, Marc Bloch, Philippe Aries, De Lima, Fernand Braudel and Jacques Le Goff), who introduced the foundations of the New Historical Science based on the need and possibilities for reconstructing historical and social facts. A. Gurevich called its representatives the "practicing historians" (Gurevich, 1993: 30). Special consideration should be given to the thorough 3-volume work of the French historian Fernand
Bradeel "Material Civilization, Economics and Capitalism, XV-XVIII centuries", and more specifically the last chapter of the first volume - "The structures of everyday life: Possible and Impossible", which is called "Cities". Here, the author embodies all the historically significant events into urban background, considering such issues as cities hierarchy, cities and civilization correlation, cities as free worlds, whether it is possible to simulate the forms of a western city. Braudel presents a city, perhaps for the first time, as the civilization embodiment (Braudel, 2006: 447).

On the other hand, the so-called "spatial turn" occurs during this period, which led to "spatial debate" in human sciences. A new approach to space was characterized not only by a look at urban phenomena, but also by identifying and studying reality in general, in terms of spatial parameters and "space" category (Fen, 2012). Its articulation is attributed to Henri Lefebvre, who, using the Marxist methodology, proposed the idea of producing a social spa$\mathrm{ce}$, its production. Since publication of Space Production, the tendency emerged to see spaces everywhere regardless of physical availability: the space of the text, space of the meaning, space of the communication and space of trust, etc. David Garvey developed and distributed Lefebvre's ideas in urban development.

The Ukrainian philosophical thought gives rise to the beginning of this work in L. Radionova's philosophy of the city, where she proposes "to build a city in the cultural space as a kind of ontological idea that has its own history, 
biography, trajectory of formation - as some ideal archetype with possible branches into the European, Oriental and other variants" (Radionova, 2013: 273-274), with a view of the city as the world of human existence in M. Karpovets (2014) or representing the idea of the city as its myth (Belokobylskiy, Sidorova, 2013).

Purpose. Proceeding from this background, this article is tried to answer the question: what is the form of "city's elusive spirit" (V. Benjamin), and how can we research it.

Presentation of the basic material. Powerful urban school was a School of Sociology at the University of Chicago. Intensive urban development in the 20's of XX century virtually turned Chicago into a laboratory for researchers. The most prominent representative of this trend is Lewis Mumford, who created a comprehensive concept of urban origin and development. In his work "The Culture of Cities" he advanced and substantiated the typology of the cities, the first of which was called a medieval city, "perfect" in terms of the urban environment structure and particular way of life, with its subordination to the Christian Church and a special system of values (Mumford, 1970: 70-71), that is markers of the corresponding era. Cities being created in the new era and later have a predominantly industrial orientation (developed due to the need to meet industrial needs). Mumford's point of view that the city, above all, is a social formation, was reflected in the interpretation of the industrial city and its features. According to Mumford, the industrial city is based on the mechanistic integration and social gap (Mumford, 1970: 157-161). The researcher, under the influence of technological development introduced the term "Megamachine" to indicate the issue of human life being absorbed by technology and of person being conquered by technology and put in service for it. Industrialization enriched the urbanist theory of Mumford's concept of a city as civilization machine.

Other representatives of this trend, in particular, Lewis Wirth, Robert Park and Kevin Lynch, studied the relationship between the social and spatial aspects of the city. Kevin Lynch is the author of the urban mental maps theory, the idea of mental image of the city and development of the urban form theory in its dependence on the perception of urban environment by its inhabitants. "The Image of the City" emerges in the mind of urban resident due to a clear and structured environment with forms that produce strong images. Such an image can be both individual (in author's opinion it should be of interest to psychologists) and collective as well. It is "public images", common mental images that are inherent in most citizens, resulting from the manifestation of consensus (Wirth, 2005), group images and is the subject of Lynch's curiosity. The researcher aims to design such environments (cities) that in addition to being well organized will be poetic and symbolic, taking into account historical traditions of individuals, their travel strategies, will contribute to the reproduction of the identity vitality (Lynch, 1992).

The concept of image of the city that a man grasps has evolved into idea of dependence and conditionality of human feelings and mood on urban space surrounding us, the space of our everyday lives. The last thesis is defended by professor of psychology Colin Ellard, who is a pioneer in the field of psycho-geography (studying how the environment affects us) and specializes in cognitive neuropsychology.

Colin Ellard in his book "The Habitat of Existence: How
Architecture Affects Our Behaviour and Well Being", talks about the key role of emotion in managing our daily behaviour; emotions themselves, and even the way of thinking, depending on the space where we stay. The researcher writes: "I am personally convinced, the key to creating a better living environment at all levels is to identify a complex relationship between our life experience and the places where it was acquired" (Ellard, 2015). Ellard offers a contrasting example with St. Peter's Cathedral in Rome and everyday architectural impressions to illustrate the thesis. The researcher describes how the visitors of the Cathedral dipped their feet from the contemplation of the majestic dome with unsurpassed paintings; according to the author, this experience makes them think about their place in the universe, reject fears and believe in the possibility of eternal life (actualization of the religious context). This experience is able to control the behaviour of visitors long after the visit to the walls of the Cathedral. On the other hand, visits to such administrative structures, such as the court, give rise to a feeling of our insignificance before the power of authority. According to psychologists, the contemplation of such spaces affects our behaviour, makes us more humble and anonymous to each other. Ellard's developments are made on the verge of urbanism and psychology, can complement the method of his predecessor, the Boston sociologist and urbanist Kevin Lynch, which includes mental mapping of urban space.

Another Chicago School's area of interest is the "ecological urbanism" by Robert E. Park. This approach resembles the initial provisions of geographical determinism, developed in the 18th century by Charles Montesquieu, according to which the geographical position determines the conditions for the existence of societies, the influence of which forms the customs of people, imposes a certain character of economic practices, one or another political system. Robert Park attributes to the local geography the role of determinants in the development of the city. This author writes: "The main outlines of the modern city will be determined (1) by local geography and (2) the routes of transport. Local geography, transformed by railways and other main vehicles, which are invariably associated with the major industries, determines the general contours of urban planning" (Park, 2006: 14). The author develops his opinion in the following direction - the urban community is actually much more complicated than can be understood from attempts to describe it, besides, different types and sizes of cities have their own particular variations. The main thing, however, is that communities tend to gravitate towards a particular pattern and this pattern is consistently manifested in the constellation of typical urban areas that can be geographically localized and spatially defined.

The author compares the city with the sieve: "once founded, the city turns out to be a great sieve, which unmistakably chooses from the population of the country as a whole those who are best suited to live in this area or in this environment". All this emphasizes the importance Park assigns to location, position and mobility as indicators necessary for measuring, describing, and, finally, explaining the social phenomena (Park, 1967). Robert Park's followers, including Hawley, present their vision of the urban environment and development of its areas by analogy with the processes occurring in the natural environment. 
Another important area of Chicago School's interest is the Lewis Wirth concept, which is to look at urbanism as a way of life. Captured by the rapid pace of urbanization, the researcher wrote: "Growth of cities and urbanization of the world - one of the most striking facts of the modern era" (Wirth, 2005: 93-118). The point here, according to Wirth, is not even in the number of urban population, that is, those who lead the urban way of life. The fact is that cities have started to exert a significant influence on the social life of a person, because the city is not a place of life and work for a modern person, but a centre that regulates economic, political and cultural life. The city becomes a centre that, on a global scale, attracts the most remote communities of the globe to its orbit and unites into a single space, an ordered system of different territories, people and activities. Thus, according to Louis Vuitton, urbanism acts as a form of social existence, a way of life.

The Chicago School's developments are being criticized by the modern research team at Darmstadt University, indicating that the city itself as an independent object is lost in numerous studies of the urban life. After all, in their opinion, various quantitative measures of the citizens' life are not identical to the city itself. The city is not a "society" subcategory, a laboratory of social processes. Even "new urban sociology" trend at the end of the XX century, which focused on economic urban indicators, has replaced the city as a subject of research into society "guided by the assumption that the structural problems of capitalism, the relations of inequality and patterns of exploitation will be reflected in the city as if in a drop of water" (Berking, 2017: 8). Researchers perceive a fundamental decision to take off the table the city with all its differences and local peculiarities as a research object of the social sciences to be the result of concepts of modernity postulating the determinism of the social development dynamics. Such an approach gives the city no chance to be considered as local factor for social progress.

Does the emphasis change of what exactly the urban researcher studies: urban societies or the city itself? Modern researchers suggest to shift the research focus from urban social processes to the city itself using the concept of "The intrinsic logic of cities" by Helmuth Berking and Martina Löw of Darmstadt University. The city is viewed not only as a homogeneous mirror of social processes, but each city is marked by its own individuality, and develops in its own unique way. The own concept of these researchers (Helmuth Berking and Martina Löw, Peter Goering, Rolf Lindner, Jürgen Hasse) is presented in the paper "The intrinsic logic of cities. New Approaches to Urbanism", which was the result of a series of interdisciplinary workshops, and where an alternative concept to the previous urbanistic tradition has been formulated to consider the city as merely a mirror of social processes. By the example of European cities such as Manchester and Sheffield, Berlin, Hamburg and Frankfurt, the authors explain what they mean by the "own logic of the cities". This is a new research approach designed to conceptualise and empirically explore the "city" and cities as special subjects of study in all their peculiarities. This is an idea of a locally specific peculiar reality of the cities (Berking 2017; Löw 2017: 7-11).

The authors note the processes of strengthening local phenomena and the role of the city under the influence of globalization processes dynamics (Berking 2017; Löw
2017: 11) with the simultaneous weakening of the national state and trying to answer the questions remaining unexplained in urbanism after a "cultural turn" in human and social sciences. It is about the role of the cumulative structures of local cultures, their settling in material environment of the cities or in the city as a collective memory, about local "structures of feeling", about "habitus", "individual look" or "biography" of the cities.

Another system is worth of attention - the multidisciplinary approach to the city- SPACE (D). SPACE (D) is the abbreviation for first letters of the English names of several areas in societal research, explained as Sociology, Politics, Architecture, Culture, Economics, Data (Sitar, 2013) and accordingly focuses on the city in terms of society, governance, architecture, city culture, urban economy, data about the city. This idea was used in the "Archaeology of the periphery" project for the Moscow Urban Forum 2013 by MEGANOM team, Institute of Media, Architecture and Design "Strelka". The project itself was focused on studying the relationship between the centre and the periphery, and was based on four key points: 1) interdisciplinary equality; 2) relevant set of six "monodisciplinary" trends on which the SPACE (D) study was based; 3) use of techniques in accordance with the constant practice of each of the SPACE (D) trend; 4) synthetic and heuristic value, as well as the fundamental restrictions of the interdisciplinary approach, which appeared in the process (Sitar, 2013: 200).

A number of modern multidisciplinary urban studies based on a mixed methodology should be complemented by such trends as myth geography, or cultural geography. The pioneer in this direction was the American scientist of Chinese origin, I-Fu Tuan, who is considered the classicist in distinguishing between "place" and "space". According to the researcher, "Space" and "Place" are similar words denoting general experience. We live in a space. Limiting this simple - we create a place. The author writes that "place is security, space is freedom: we are tied to one and depend on another" (Tuan, 2002: 3). I-Fu Tuan's concept of Space and Place is to determine the space and place as main components of the living world. Investigating human relations, human-nature relations, geographical behaviour of people the author gradually shows how exactly we are shaping the image of place. First, this happens with visibility. A place is a collection of objects covered by our attention. However, the place, according to the author, has a history and meaning, and embodies the experience and aspirations of people. That is, the place depends on its interpretation by a person. This is a reality endowed with certain meanings by a person. "Space", according to Tuan, is a "sterile" open area that has no social connections for a person. "Place", on the contrary, is created by human experience, it is part of the space and full of meaning and purpose of human experience within this space. It manifests itself to a person through objects of art, architecture, monuments, and others.

\section{Conclusion}

Thus, having considered the most common theoretical and methodological approaches to the analysis and definition of the city, we see that modern authors repeatedly draw attention to the need for a holistic approach to the phenomenon of the city, and tend towards multidisciplinary urban studies. An interdisciplinary approach in urban studies allows you to focus on the components (structures 
- architecture, significant places, communications, public and private spaces) the city consists of, and which create the cultural code of European society.

At the present stage, in the face of civilizational crises and collision of various cultural installations deployed in urban areas, it becomes clear that the city is not only an arena for these processes, but also sometimes a condition to them, an active participant and, eventually, their consequence. In this regard, appealing to such topics as the myth of the city, memory in the city or the return of scientific interest to sacred urban spaces looks promising. One can see that a need emerged to develop a theory of the city that could cover both the city as a dynamic cultural form in general and specific processes that take place in urban environments as well.

\section{REFERENCES}

Belokobylskiy, A. \& Sidorova, K. (2013). The Donetsk's myth. Ontology of the city's self-definition, Skhid, Vol. 126, Issue 6, p. 265-269. Retrieved from http://skhid.kubg.edu.ua/article/view/ 20724 (In Ukrainian).

Braudel, F. (2006). Material Civilization, Economy and Capitalism, the XV-XVIII Centuries. Vol. I. Structure of Everyday Life: the Possible and the Impossible. Transl. From French. Moscow, 592 p. (In Russian).

Ellard, C. (2015). Places of the Heart: The Psychogeography of Everyday Life. Bellevue Literary Press, 255 p. (In English).

Fen, E. G. (2012). The main categories of phenomenological philosophy of space in modern research on the city. [Doct. Diss.]. Moscow, 142 p. (In Russian).

Gurevich, A. Ya. (1993). Historical Synthesis and School "Annals". Moscow, 327 p. (In Russian).

Karpovets, M. (2014). City as the world of human existence. Ostroh: Vyd. NaUOA, 258 p. (In Ukrainian).

Lynch, K. (1992). The Image of the City. Cambridge: MIT Press, 194 p. (In English).

Mumford, L. (1970). The culture of cities. A Harvest/HBJ Book, Publishers, NY, 586 p. (In English).

Park, R. (1967). The City as a Social Laboratory. Selected Papers, Ed. and with introduction by Ralph $H$. Turner. Chicago a. London: Phoenix Books, The University of Chicago Press: 3-18 (In English).

Park, Robert (2006). Gorodskoe soobshchestvo kak prostranstvennaya konfiguratsiya i moralnyy poriadok [The Urban Community as a Spatial Pattern and a Moral Order]. The Russian Sociological Review, 1: 11-18. Retrieved from https://sociologica.hse.ru/en/2006-5-1/27479014.html (In Russian).

Prepotenskaya, M. P. (2014). Homo urbanus: the phenomenon of megacity human. Dnipropetrovsk: Publisher. T.K. Serednyak, 420 p. (In Ukrainian).

Radionova, L. (2013). Public space of city in social-philosophical prospect: methodology of research. Skhid, 6 (126): 273-277. Retrieved from http://skhid.kubg.edu.ua/article/view/20742 (In Ukrainian).

Sitar, S. (2013). SPACED: Interdisciplinarity and a Humanitarian Shift. Archaeology of the Periphery. Research for the Moscow Urban Forum, Moscow: Meganom, 200-207. Retrieved from http:/ /mosurbanforum.com/media/-library/2013_archeology_of_the_periphery.pdf (In Russian).

Berking, H. (ed.), \& Löw, M. (ed.) (2017). The intrinsic logic of cities: new approaches in urbanistic. Moscow: New Literary Review, 424 p. (in Russian).
Tuan, Yi-Fu. (2002). Space and Place. The Perspective of Experience. Minneapolis - L.: University of Minnesota Press, 262 p. (In English).

Weber, M. (2001). The City: History of economy. Moscow: Canon Press-C; Kuchkovo field, 576 p. (In Russian).

Wirth, L. (2005). Selected works on sociology. Moscow, pp. 93-118 (In Russian).

\section{LIST OF REFERENCE LINKS}

Білокобильський О., Сидорова К. Міф Донецька. Онтологія самосвідомості міста. Схід. 2013. № 6 (126). С. 265-269. URL: http://skhid.kubg.edu.ua/article/view/20724 (дата звернення: 11.12.2018).

Бродель Ф. Материальная цивилизация, экономика и капитализм, XV-XVIII вв. Т. 1. Структуры повседневности: возможное и невозможное. Москва: Издательство "Весь Мир", 2006. 592 c.

Вебер М. История хозяйства: город. Москва: Канонпресс-Ц, Кучково поле, 2001. 576 с.

Вирт Л. Избранные работы по социологии / Пер. с англ. В. Г. Николаева. Москва, 2005. С. 93-118.

Гуревич А. Я. Исторический синтез и Школа "Анналов". Москва: Индрик, 1993. 327 с.

Карповець М. Місто як світ людського буття: монографрія. Острог: Вид-во НаУОА, 2014. 258 с.

Парк Р. Городское сообщество как пространственная конфигурация и моральный порядок. Социологическое обозренuе. 2006. Том 5. № 1. C. 11-18. URL: https://sociologica.hse.ru/ en/2006-5-1/27479014.html (Дата звернення 02.12.2018).

Препотенська М. П. Homo Urbanus: френомен людини мегаполісу: монографія. Дніпропетровськ: Вид. Середняк Т. К., 2014. $420 \mathrm{c}$.

Радіонова Л. Публічний простір міста в соціально-філософській перспективі: методологія дослідження. Схід. 2013. № 6 (126). C. 273-277. URL: http://skhid.kubg.edu.ua/article/view/ 20742 (Дата звернення 13.12.2018).

Ситар C. SPACED: междисциплинарность и гуманитарный поворот / Археология периферии. Исследование для Московского урбанистического форума. Москва: Меганом, 2013. C. $200-207$. URL: http://mosurbanforum.com/media/library/ 2013_archeology_of_the_periphery.pdf (Дата звернення 04.12.2018).

Собственная логика городов: Новые подходы в урбанистике / Коллективная монография; под отв. ред. Хельмута Беркинга и Мартины Лёв. Москва: Новое литературное обозрение, 2017. 424 с.

Фень Е. Г. Основные категории феноменологической философии пространства в современных исследованиях города: дисс. ... канд. филос. наук. Москва, 2012. 142 с.

Ellard C. Places of the Heart: The Psychogeography of Everyday Life. Bellevue Literary Press, 2015. 255 p. $194 \mathrm{p}$.

Lynch K. The Image of the City Cambridge: MIT Press, 1992.

Mumford L. The culture of cities Harcourt, Brace and company, 1938. $586 \mathrm{p}$.

Park R. The City as a Social Laboratory. Selected Papers, Ed. and with introduction by Ralph $\mathrm{H}$. Turner. Chicago-London: Phoenix Books, The University of Chicago Press, 1967. Pp. 3-18.

Tuan Yi-Fu. Space and Place. The Perspective of Experience. Minneapolis - L.: University of Minnesota Press, 2002. 262 p. 
Гуржи Ксенія,

Донецьький національний університет імені Василя Стуса (м. Вінниця, Украйна)

e-mail: kseniia_gurzhi@ukr.net, ORCID0000-0003-3663-6505

\section{МІСТО ТА ЙОГО ДОСЛІДНИКИ: РОЗУМІННЯ ТА ПОЯСНЕННЯ ФЕНОМЕНУ МІСТА У СОЦІАЛЬНО-ФІЛОСОФСЬКОМУ ФОКУСІ}

У статті розглянуто основні теоретико-методологічні підходи до аналізу та визначення міста. Починаючи 3 XX століття дослідники міста послуговуються новою епістемологічною методологією. 3 одного боку, це сталося завдяки Школі Анналів, представники якої виходили з можливості реконструювання історичних, соціальних фактів. 3 іншого боку, в цей період відбувається так званий "просторовий поворот" (spatial turn) в ryманітарних науках. Новий підхід до простору вплинув на спосіб визначення та дослідження реальності взагалі. Авторка зосереджує увагу на певній зміні перспективи у виборі способів дослідження міст, які віддзеркалюють зміну акцентів дослідницької уваги з соціальних процесів у місті на саме місто. Це призводить до появи нових мультидисциплінарних розвідок у поясненні феномену міста. Йдеться про концепцію власної логіки міст дослідницького колективу Дармштадського університету, відповідно до якого кожне місто відзначається власною індивідуальністю і розвивається у своєму унікальному руслі, та систему SPACE(D), що зосереджується на місті з позиції суспільства, управління, архітектури, культури міста, міської економіки та даних про місто. Показано, що сучасні автори постійно звертають увагу на необхідність цілісного підходу до феномену міста та тяжіють до мультидисциплінарних урбаністичних досліджень. В українській філософській думці початок цій роботі покладено в філософії міста Л. Радіонової, яка пропонує "вибудовувати місто в просторі культури як якусь онтологічну ідею", в погляді на місто як на світ людського буття у М. Карповця чи представленні ідеї міста як його міфу. У висновках зазначено, що постала необхідність вироблення такої теорії міста, яка могла 6 охопити одночасно і місто як динамічну культурну форму загалом, і конкретні процеси, що відбуваються в міському середовищі. В умовах цивілізаційних криз та зіткнення різних культурних установок, що розгортаються в міських просторах, стає зрозуміло, що місто є не лише ареною для цих процесів, а й іноді їх умовою, активним учасником та врешті - їх наслідком. Розвиток і зростання міст в умовах глобалізації наочно демонструє, що міста не тільки не однакові, але навіть розвиваючись в загальному контексті і маючи однакові вихідні позиції, кожне конкретне місто поставлене завдання вирішує по-своєму. Тому хоч і враховуємо теорії "глобального міста", в кінцевому підсумку, все одно звертаємося до досвіду цілком конкретних міст.

Ключові слова: фрілософрія міста; власна логіка міст; міфр міста; урбаністичний дискурс.

(C) Hurzhy Kseniia

Надійшла до редакції: 14.12.2018

Прийнята до друку: 18.02.2019 